\title{
ILUSTRACIÓN VERSUS RELIGIOSIDAD POPULAR. EL CASO DEL REINO DE GRANADA
}

\author{
Serafín Granada Marín* \\ UNIVERSIDAD DE GRANADA
}

\begin{abstract}
RESUMEN
La represión de la religiosidad popular por parte de las autoridades ilustradas durante el siglo XVIII fue una constante. Fue en la centuria del setecientos, la época en la que desde el Consejo de Castilla, con el conde Aranda y Campomanes al frente, se intentó poner límites al desenfreno de las celebraciones religiosas del pueblo. Los ilustrados quisieron imponer su nuevo tipo de religiosidad, mucho más intimista y personal, alejada de las grandes manifestaciones barrocas de piedad. Las hermandades del entonces reino de Granada, que englobaban las provincias de Granada, Málaga y Almería, no escaparon al riguroso control ilustrado. La principal institución represora fue el arzobispado granadino.
\end{abstract}

PALABRAS CLAVE: cofradía, hermandad, ilustrado, Ilustración, religiosidad

*granadamarins@gmail.com 


\title{
ENLIGHTENMENT VERSUS POPULAR RELIGIOUSNESS. THE PARTICULAR FACT OF THE KINGDOM OF GRANADA
}

\author{
Serafín Granada Marín* \\ UNIVERSIDAD DE GRANADA
}

\begin{abstract}
The repression of popular religiosity by enlightened authorities during the eighteen century was a constant. It was at that time when the Council of Castile, which the Count of Aranda and Campomanes in the lead, tried to put limits to the unbridled religious celebrations of the people. The enlighteneds ones wanted to impose their new type of religiosity, much more intimate and personal, far from the great baroque manifestations of piety. The brotherhoods of the Kingdom of Granada which included the departments of Granada, Málaga y Almería, did not escape the rigorous control of the enlighteneds. The main repressive institution was the archbishop of Granada.
\end{abstract}

KEYWORDS: brotherhood, confraternity, enlightened, Enlightenment, religiousness

Enviado: 2-11-2019

Aceptado: 15-1-2020

*granadamarins@gmail.com 


\section{ESTADO DE LA CUESTIÓN}

Los estudios sobre la religiosidad popular han aumentado tanto en número como en calidad en los últimos treinta años. Este trabajo se va a centrar en la segunda mitad del siglo XVIII, época en la que los miembros del Consejo de Castilla y las autoridades eclesiásticas quisieron controlar el asociacionismo laico que se producía en torno a las cofradías.

Arias de Saavedra Alías y López-Guadalupe Muñoz (2002) definen la cofradía como "una importante célula social, el cauce asociativo más generalizado de toda la Edad Moderna". De ahí que las élites gobernantes civiles y eclesiásticas se esforzaran tanto por su dominio.

Un acontecimiento fundamental para entender la Historia de las cofradías y las hermandades en la Monarquía Hispánica, es la tramitación del Expediente General de Cofradías del Reino ${ }^{1}$. Su pretensión era recoger información sobre la situación de las cofradías de distintos territorios de la Corona para tener una justificación por parte del gobierno para aplicar una legislación restrictiva sobre ellas.

Álvarez Santaló (1991) asegura que el conflicto no se produce por cuestiones dogmáticas sino disciplinares, temporales y económicas. Esta hostilidad solo tiene lugar entre las élites, entre el rey y el papado. Las clases bajas estaban muy alejadas de este enfrentamiento dialéctico.

Uno de los autores pioneros en el estudio de este tema fue Rumeu de Armas $^{2}$. En un tono bastante crítico se refiere a las cofradías y hermandades como instituciones decadentes sin objetivos religiosos ni benéficos. Para el autor solo se reunían para hacer "comidas y refrescos".

Por el contrario, para el estudioso Farid $\mathrm{Abbad}^{3}$, tanto el conde de Aranda como Rodríguez Campomanes eran simples conductores de la acción gubernamental siguiendo el pensamiento ilustrado. Para esta élite

1. M. L. López-Guadalupe Muñoz e I. Arias de SaAvedra (2002), 180. Este amplio expediente, tanto por su extensión como por su duración, nos muestra una fotografía fija de la situación de las cofradías en la segunda mitad del siglo XVIII. Las élites políticas y religiosas dan su opinión en diversos escritos, las cuales no son favorables, por lo general, hacia estas asociaciones de feligreses.

2. A. Rumeu de Armas (1944), 59. En esta obra se recoge un pensamiento un tanto mediatizado por la cultura de su tiempo, en la que los ilustrados no tenían buena prensa entre los intelectuales españoles.

3. F. ABBAD (1977), 376. En este breve artículo este hispanista hace un recorrido por las fases que recorrieron las cofradías en el reinado de Carlos III. 
cultivada la vida debía ser conducida por el rigor, la voluntad, la templanza, el orden y la moderación.

La crítica del modernista Teófanes Egido ${ }^{4}$ es que el estudio de la religiosidad en el pasado ha sido tardío. Sobre el siglo XVIII manifiesta que se lo ha tachado de maldito, por la irreligión que parecen tener las élites y su antihispanismo. Los ilustrados no querían destruir la religión ni tampoco descristianizar España.

Por último, destaca la afirmación de Mantecón Movellán (1990) en la que argumenta que todo lo relacionado con lo festivo alertaba a las altas jerarquías eclesiásticas, sobre todo a partir de la segunda mitad del siglo XVIII. El Estado Ilustrado quería tener un mayor control de todos los actos celebrados, velando siempre por el orden público y en contra de la ociosidad improductiva.

Conforme a lo anteriormente expuesto, cabe concluir que el estudio de las hermandades y cofradías ha tenido una época de auge en los últimos años. En asuntos como la crítica ilustrada y el reinado de Carlos III, en cuestiones de conjunto ${ }^{5}$ y otras más localizadas en regiones españolas ${ }^{6}$. También encontramos obras que recogen el fenómeno cofrade desde una óptica social ${ }^{7}$. Son muy interesantes algunos análisis a nivel andaluz, tanto de la parte oriental ${ }^{8}$ como de la parte occidental ${ }^{9}$.

Es necesario destacar investigaciones referentes a las desamortizaciones cofrades ${ }^{10}$ pasando por la acción social y asistencial de estas instituciones ${ }^{11}$ y como no, con el análisis de las consecuencias de las reformas por parte de las élites castellanas ${ }^{12}$.

4. T. EgIDo (1990), 177. Gran parte del siglo XX ha sido crítico con el pensamiento ilustrado y sus representantes por considerarlos contrarios a los valores de la nación española, sobre todo en los sectores más conservadores.

5. M. ROMERo SAMPer (1990).

6. I. Arias de Saavedra y M. L. López-Guadalupe Muñoz (2008).

7. I. Arias de SaAvedra y M. L. López-Guadalupe Muñoz (2017).

8. E. Gómez Martínez (2008).

9. R. Plaza Orellana (2018).

10. M. A. López Arandia (2003).

11. C. Lozano Ruiz (2013).

12. A. Martín García (2006). 


\section{ANÁLISIS DE LAS MEDIDAS CONCRETAS}

\subsection{La acción contra la Semana Santa y otras devociones de Pasión}

Una de las festividades más castigadas por las reformas ilustradas fue la Semana Santa. Este hecho no fue algo casual, puesto que en estos días del año se producía una enorme afluencia de procesiones penitenciales en todo el territorio granadino. Como estudió López-Guadalupe Muñoz ${ }^{13}$, ya desde la misma fundación de cofradías que realizan estación de penitencia, se intentó controlar a estas, por parte de las autoridades eclesiásticas y estatales correspondientes, aunque se consiguieron pocos resultados.

Una cédula real, en la que se prohibían los disciplinantes en las procesiones de Semana Santa es promulgada en $1777^{14}$.

Este ingente control se puede observar hasta en el más mínimo detalle, como es en la forma de sacar una procesión en Semana Santa. Como ocurrió en 1774, año en el que, Francisco Campos, hermano mayor de la hermandad de Jesús de las Tres Caídas, ubicada en el convento de San Francisco Casa Grande ${ }^{15}$, pide licencia al arzobispo Barroeta y Ángel para sacar la procesión de una forma determinada. El notario de la audiencia episcopal le requiere el libro de cabildos para saber lo que se anotaba en las juntas de hermandad sobre este tema. Tras su lectura, este ministro eclesiástico decide que no puede salir en procesión, lo que hace enfurecer a los hermanos, "clamaron una, dos y tres veces, dos oficiales renunciaron a sus empleos y que iban a sacarla, pues eran muy hombres y para que estuvieran contentos"16.

Además, en el propio seno de esta reunión de hermanos había vicisitudes sobre si sacar o no la procesión, puesto que no había suficientes

13. M. L. López-Guadalupe Muñoz e I. Arias de SaAvedra, (2002), 110. En las reuniones del cabildo general de cada hermandad era obligado que asistiera un ministro eclesiástico para garantizar el sosiego.

14. Archivo Histórico Municipal de Granada (AHMG), caja 01194, n. ${ }^{\circ} 0020$, sin foliar. Prohibición de disciplinantes por el Consejo de Castilla, 1777.

15. Archivo Histórico Diocesano de Granada (AHDG), caja 34F(B), n, ${ }^{\circ} 5$, sin foliar. Auto sobre la salida procesional de la hermandad del Cristo de las Tres Caídas de Granada, en la que intervino la autoridad eclesiástica, y la municipal. Esta intromisión de debió a las disputas en la junta de la hermandad que no se ponía de acuerdo en si sacar la procesión o no, puesto que no había dinero ni horquilleros suficientes que la portaran. Todo se produjo por unos supuestos robos del hermano mayor del arca donde se guardaba el dinero.

16. AHDG, caja $34 \mathrm{~F}(\mathrm{~B}) n .^{\circ} 5$. 
horquilleros, ya que habían faltado seis horquillas por vender y se echaron las culpas entre el capellán, Antonio Díaz, y el hermano mayor. El notario les advierte que si no guardan armonía y formalidad se procederá a la suspensión. El cabildo municipal se entromete en esta disputa, oponiéndose al desfile procesional, puesto que podía provocar graves desazones y escándalos notables en un sitio sagrado, incluso expone que podría haber alguna muerte o robo.

Entonces la hermandad decide elegir a un nuevo mayordomo y un hermano mayor, los cuales se implican más en esta labor y consiguen los horquilleros suficientes. Así se acabó el pleito en la hermandad y el cabildo consideró la marcha procesional en positivo a cambio de 172 reales de vellón.

Unos años después, en 1777 en la capital granadina Antonio de la Plaza, canónigo de la catedral y provisor de la diócesis, pedía permiso al arzobispo Jorge y Galbán para sacar en estación de penitencia la imagen de Nuestra Señora de la Soledad, ubicada en el convento del Carmen. Justifica que se debe a la "discorde situación en que están los ánimos entre los hermanos"17.

A la misma vez, se pide el permiso para otra salida, en este caso proveniente de la parroquia de San Gil, la hermandad con el título de las Tres Necesidades quiere procesionar porque se estaban produciendo numerosos desórdenes e inquietudes entre los fieles en esos días. En realidad, en virtud de una concordia estas dos cofradías (ambas del Entierro de Cristo) procesionaban alternativamente, una cada año, desde poco tiempo atrás.

El arzobispo Jorge y Galván niega la licencia para permitir estas salidas procesionales, "evitando turbación y escándalo que es de tener en el estado del resentimiento y quejas en que se advierte a ambas procesiones" 18 . Seguidamente manda un mensaje al presidente de la Real Chancillería refiriéndole lo siguiente, "en esta santa determinación muy conforme a la piadosa intención, intente desestimar qualquier recurso que intenten hacer qualquiera de las dos hermandades y se eviten los grandes prejuicios y se logrará tranquilidad que todos apetecemos" 19 .

En 1791, en la localidad de Motril se produjo una de las desavenencias más largas en el tiempo entre la autoridad episcopal y una hermandad de la villa ${ }^{20}$.

17. Archivo de la Real Chancillería de Granada (ARChG), leg. 4430, n. ${ }^{\circ}$ 28, sin foliar. 1775.

18. ARChG, leg. 4430, n. $^{\circ} 28$, sin foliar.

19. ARChG, leg. 4430, n. $^{\circ} 28$.

20. M.L. López-Guadalupe Muñoz (2002), 197. El conflicto fue de tal entidad, que incluso el arzobispo tuvo que pedir ayuda al rey para que mediara, también le pedía más 
Se trata de la cofradía de Jesús Nazareno, venerada en la iglesia colegial y parroquial. Piden permiso para hacer su estación de penitencia el Viernes Santo por la mañana por "la mucha fe que justamente tienen en el señor que les bendiga los campos, frutos y todos los moradores, excita el fervor de los fieles cuando se saca, sin desviarse el fervor de los fieles, sin desviarse de la penitencia" 21 .

Dentro de la hermandad, un grupo de gente notable pedía distinguirse del resto de hermanos portando unas insignias determinadas, son los llamados blandonistas, los cuales estaban enfrentados a los suplicantes.

El arzobispo Moscoso y Peralta resolvió que no debía "haber devoción de estados"22, por lo que denegó la licencia. Pese a esta negativa, en 1794 la procesión se hizo. Tiempo después, interviene el presidente de la Real Chancillería de Granada para pedir testimonio de toda persona que tenga las constituciones, el decreto de fundación de la hermandad y los edictos episcopales que prohibieron este paso.

El arzobispo cede y concede licencia para la procesión, no obstante, hubo una disputa interna porque en la junta de hermandad se votó en contra de que salieran los blandonistas. Por ello, el gobernador de Motril paraliza la salida procesional por este pleito entre la hermandad y el paso de los blandonistas.

En el año de 1795, ante la insistencia de los motrileños, el arzobispo vuelve a conceder permiso para la celebración de la procesión, pese a las quejas del gobernador. El problema vino de nuevo por parte de los blandonistas que se oponían a sacarla si ellos no salían en una posición preferente. Pero una enorme multitud de personas se presentó en la plaza quejándose de estas exigencias de los hermanos blandonistas, hubo numerosos disturbios, por lo que el gobernador tuvo que volver a anular este paso.

Asimismo, durante el año 1795, el arzobispo Moscoso y Peralta quiso cambiar alguna de las constituciones de la hermandad del Santísimo Cristo del Paño de la villa de Moclín. A su juicio el orden en que se hacía la inversión de las limosnas era un tanto caótico, porque se mezclaban los granos, el dinero y la cera.

severidad con esta cofradía de Jesús Nazareno que celebraba su estación de penitencia sin ninguna licencia, ni real, ni eclesiástica.

21. AHDG, caja $222 \mathrm{~F}(\mathrm{C}), \mathrm{n}^{\circ}{ }^{2}$, sin foliar. Legajo sobre el pleito de la cofradía motrileña y el metropolitano, 1794.

22. AHDG, caja $222 \mathrm{~F}(\mathrm{C})$, n. $^{\circ} 21$. 
Tampoco permitió que los sacerdotes dijeran tantas misas como los labradores de los cortijos les pidieran, para ello, instó a los ministros eclesiásticos a nombrar varios tenientes de cura para que los sustituyeran cada quince días.

Otro punto de conflicto fue la elección de mayordomos cada año. Debían presentar las cuentas en su secretaría de cámara para poder ser reelegidos y darles licencia.

Por último, prohibió que el sacristán fuese el encargado de "cuidar de poner y recoger cera y lámparas de Cristo" 23 ni "poner cera a la imagen con dos ducados de multa al teniente sacristán".

Algarinejo ${ }^{24}$ fue una de las poblaciones que más sinsabores dieron al arzobispo Moscoso y Peralta en los años finales del siglo XVIII y de principios del siglo XIX. En 1798 el prelado manda una orden a la ermita del Santísimo Cristo de la Vía Sacra situada extramuros de la villa para que no pida limosnas sin su licencia bajo pena de excomunión, para evitar los alborotos que se produjeron en años anteriores.

Al año siguiente, las hermandades del municipio piden permiso al arzobispo para sacar procesiones. La respuesta episcopal no se hizo esperar y fue afirmativa, pero siempre que "el vicario observe circunspección y decoro y que el gobernador y la justicia real se encargue de evitar desórdenes ni escándalos" ${ }^{25}$. Sin embargo, prohibió el paso de Jesús, que se hacía el Jueves Santo por la tarde, por sus representaciones irrisibles y ridículas. A esto se añadió que el cura ecónomo, encargado de recibir la orden, no estaba en la iglesia, algo que parece que acostumbraba a hacer. La autoridad episcopal le sanciona con 20 ducados de multa y si volvía a ocurrir se le suspendería de su curato.

A la misma vez en 1798, en la localidad de Órgiva, el metropolitano Moscoso y Peralta envió un edicto prohibiendo que en las procesiones salieran "penitentes, las doce tribus, ángeles, las Marías, verónicas y el paso de Longinos"26. Tampoco se libraron "las soldadescas, tiroteos, mojigangas y otros excesos". Para que no pudiesen alegar ignorancia las hermandades,

23. AHDG, caja $222 \mathrm{~F}(\mathrm{C}), \mathrm{n}^{\circ} 31$, sin foliar. Auto episcopal, en el que se enumeran las modificaciones que deben ser realizadas en las constituciones de la cofradía a cambio de la licencia pertinente de poder procesionar. No se conserva ni la causa de este escrito ni la respuesta por parte de la hermandad afectada, 1795.

24. AHDG, caja $222 \mathrm{~F}(\mathrm{C}) \mathrm{n} .^{\circ} 3$, sin foliar. Auto para pedir permiso al arzobispo sobre si pueden sacar las procesiones de penitencia en Semana Santa como cada año se hace. Con el posterior enfado del prelado por no seguir el procedimiento establecido, 1798.

25. AHDG, caja $222 \mathrm{~F}(\mathrm{C}) n .^{\circ} 3$.

26. AHDG, caja $222 \mathrm{~F}(\mathrm{C}) \mathrm{n} .^{\circ} 3$. 
les envío una copia de este documento a cada sacerdote y vicario del lugar. Además de hacer ir al párroco de la villa a Granada para que compareciese por permitir estas prácticas profanas.

En 1801, en este mismo lugar, se denuncia una representación teatral de Jesús y sus apóstoles en la escena de la sagrada cena. Consistía en sacar a la imagen de la Virgen de los Dolores que movía los brazos para abrazar a la persona que interpretaba a Cristo. A continuación se representaba la escena de los azotes en la columna y la parte en la que Jesús portó la cruz a cuestas. Lo más curioso era que el propio párroco del lugar era quien se disfrazaba del Mesías.

La persona que denuncia estos hechos no fue un clérigo, como sería lo lógico, sino un pintor de la villa que fue como testigo a declarar ante el arzobispo Moscoso y Peralta con testimonios como "bajo su conciencia testifica mil ridiculeces que excitan más la diversión que la devoción"27. Es fácil imaginar el enojo del metropolitano cuando escribía, "enciende la piadosa indignación de cualquier persona que tenga sentimientos religiosos"28. El prelado prohíbe esta escenificación bajo pena de excomunión, también prohíbe todos los pasos de Semana Santa y al cura lo suspende de su ministerio.

La noticia se recibió con una enorme pesadumbre en la villa, por lo que se escribió al arzobispo pidiendo su compasión para con los pasos de Semana Santa y se argumentaba que se hacían con devoción y sin irrisión.

\subsection{La ardua persecución contra las cofradías}

Las justificaciones más comunes de los prelados y funcionarios reales para intervenir en una cofradía eran los abusos que cometían. Un ejemplo lo tenemos en el año 1786 en la villa de El Padul ${ }^{29}$, donde se intervinieron las cuentas de hasta cuatro cofradías, la de Nuestra Señora de las Angustias, la de las Benditas Ánimas, la de San Juan Evangelista y la de San Antonio.

Es un presbítero y fiscal general del arzobispado granadino, llamado Antonio Muñoz, el que advierte de "desórdenes que se notan y abusos dignos de remedio que hay en las hermandades" 30 . Esta queja se debe a

27. AHDG, caja $222 \mathrm{~F}(\mathrm{C}) \mathrm{n}^{\circ} 3$.

28. AHDG, caja $222 \mathrm{~F}(\mathrm{C}) \mathrm{n} \cdot{ }^{\circ} 3$.

29. AHDG, caja $53 \mathrm{~F}(\mathrm{C}) \mathrm{n} .^{\circ} 11$. Informe del fiscal general del arzobispado que escribe al arzobispo para que conozca la situación en la que se encuentran estas hermandades de El Padul, 1786.

30. AHDG, caja $53 \mathrm{~F}(\mathrm{C}) n .^{\circ} 11$, sin foliar. 
que al final de cada mayordomía desaparecían misteriosamente 300 libras del arca de la hermandad.

Entonces este fiscal comenzó a pedir los libros de cuentas de cada hermandad, pero observó que en el de Nuestra Señora de las Angustias no se anotaba nada desde hacía cuatro años, por lo que dice "no consta haberse dado cuentas de limosnas recogidas" 31 . Tomó como medida que el ermitaño de la ermita que acogía esta cofradía se subordinase al cabildo y al capellán de la villa. Sobre el resto de congregaciones dice que "son de cortos caudales, son hechos a expensas de mayordomos y tienen que hacer donaciones" 32 .

Varios años antes, en 1768, el poder episcopal, con Pedro Barroeta y Ángel al frente, comenzó a examinar las cuentas de la cofradía de Nuestra Señora de los Remedios localizada en Paterna ${ }^{33}$. Francisco de Toro, un capellán ermitaño, solicitó un permiso para pedir limosna, todo con el objetivo de poder reparar la ermita y beneficiar el culto de la imagen. Pero el arzobispo Barroeta no se la concedió debido a que llevaba un año y dos meses recogiendo limosnas, de lo que no había dado ninguna cuenta al cura de la villa. El prelado envía un vicario para que investigue esta situación, se da cuenta de que todo esto venía por una enemistad entre el cura más antiguo del lugar, Juan de Campos, y este ermitaño.

En otro documento de $1768^{34}$, se descubre que el mismo arzobispo ya había dado la licencia a este capellán ermitaño para pedir limosnas durante un año, pero que debía notificarle todo al sacerdote de la villa, en lo que llaman "la cuenta más formal" ${ }^{35}$, que son las alhajas y otros objetos de valor, algo que no ocurre.

Se le envía un auto a Francisco de Toro para que entregue el libro de cuentas de la hermandad bajo pena de excomunión. Este ermitaño no le quiso entregar este documento, por lo que fue el vicario episcopal a la

31. AHDG, caja $53 \mathrm{~F}(\mathrm{C}) \mathrm{n} .^{\circ} 11$.

32. AHDG, caja $53 \mathrm{~F}(\mathrm{C}) \mathrm{n}^{\circ} 11$.

33. AHDG, caja $59 \mathrm{~F}(\mathrm{C}) \mathrm{n} \cdot{ }^{\circ} 14$, sin foliar. Auto de la cancillería arzobispal granadina para arreglar el asunto de la villa de Paterna para así poder controlar las cuentas de la hermandad de Nuestra Señora de los Remedios, de las cuales no se sabía absolutamente nada, 1768.

34. AHDG, caja $222 \mathrm{~F}(\mathrm{C}) n .^{\circ} 24$, sin foliar. Este escrito que estaba descontextualizado en el archivo pertenece a este proceso de enfrentamiento entre los dos ministros eclesiásticos de esta villa, donde el arzobispo intentó intervenir para evitar males mayores pero sin apenas resultado, 1768.

35. AHDG, caja $222 \mathrm{~F}(\mathrm{C}) \mathrm{n} .^{\circ} 24$. 
ermita a por él. Allí se dice que de Francisco de Toro "salieron palabras ignominiosas como que era un hombre sinvergüenza" y añade "otras cosas que omito por ser ambos sacerdotes" "36. También insultó al notario diciéndole falsario, por ir de noche, que había falta de libro y de luz.

Incluso en el año $1791^{37}$ el arzobispo, Antonio Jorge y Galbán, remitió una orden para que los secretarios de las hermandades de este pueblo no se entrometieran en la formación y aprobación de cuentas de las congregaciones. Esto era de jurisdicción episcopal.

Otro suceso ocurrió en El Padul durante el año 1788, cuando el párroco de la villa, Fernando José Calvo, denunció una serie de prácticas abusivas "para la justa devoción reglada de las imágenes"38. Se opuso en varias ocasiones a que se celebrasen procesiones de noche y a que se bailara dentro de las iglesias, ni en los atrios ni delante de las imágenes. Cuando pudo leer los reales decretos tuvo que intervenir.

Estas danzas se hacían en la fiesta de San Sebastián, esta imagen "se trasladó la noche anterior en público con alboroto y no poco escándalo a la iglesia parroquial" 39 . El cura explica que incluso se intentó sacar en danza el paso si no hubiera sido por su férrea oposición. También el alcalde la de la villa "lo intentó pero siendo irremediablemente revertido en esta procesión y se incorporaron las de las danzas" 40.

Entonces, el presidente de la Real Chancillería de Granada decidió intervenir y amenazó con que si se vuelven a repetir este tipo de actos habría represalias muy duras. Un cofrade, llamado Andrés de Molina, se atrevió a escribir a este alto cargo judicial haciendo una defensa de su hermandad y los actos que hacen para honrarla, "bailan por beneficios del Santísimo, bailan descalzos para curarse, les devolvió la vista a varios niños y por sanar varias heridas peligrosas" 41 .

La respuesta del sacerdote es que no se podían permitir las danzas de ningún tipo en su parroquia. El presidente de la Chancillería lo apoyó y mandó una carta al alcalde con unas instrucciones a seguir, como que las danzas estaban totalmente prohibidas. Nadie hizo caso de la orden. Unas

36. AHDG, caja $59 \mathrm{~F}(\mathrm{C}) \mathrm{n} .^{\circ} 14$.

37. AHDG, caja $222 \mathrm{~F}(\mathrm{C}) \mathrm{n} .^{\circ} 23$. Este breve documento recoge la preocupación del arzobispo por las cuentas de las hermandades de Paterna, de las que apenas tenía información, ni tampoco nadie de la villa se había preocupado por proporcionársela, 1791.

38. ARChG, legajo 1397, n. ${ }^{\circ} 03$, sin foliar, 1788.

39. ARChG, leg. 1397, n. ${ }^{\circ} 03$.

40. ARChG, leg. 1397, n. ${ }^{\circ} 03$.

41. ARChG, leg. 1397, n. ${ }^{\circ} 03$.

(C) Baetica. Estudios Historia Moderna y Contemporánea, 39, 2019, 285-300. Facultad de Filosofia y Letras, Universidad de Málaga. Departamento de Historia Moderna y Contemporánea 
jornadas después, en la procesión de la Virgen de las Angustias "salieron danzantes en deshonor al culto de Dios y en perjuicio espiritual de los demás feligreses" ${ }^{42}$

Una constante fue la solicitación de consentimiento arzobispal para poder celebrar corridas de toros por parte de las hermandades para así poder financiarse. La cofradía que más reclamó este tipo de festejos fue la de Nuestra Señora de las Angustias, patrona de Granada. En los años $1747,1785,1804$ y $1819^{43}$.

En la villa de Huéscar ${ }^{44}$, la cofradía de San Antonio Abad, igualmente, imploró al arzobispo que se festejasen dos corridas de novillos, "matando a cada uno y que su carne sea vendida para común abasto, con alguna rebaja y limosnas de fieles y devotos ${ }^{45}$ ". Se explica que esta cofradía se ha caracterizado por una gran solemnidad y culto en todas sus celebraciones

Otro proceso a destacar son los permisos para poder lanzar cohetes en las fiestas patronales o incluso en los pasos de penitencia. Como por ejemplo, el mayordomo de la hermandad del Santísimo Sacramento, ubicada en la parroquia de Santiago Apóstol en Almería, pidió licencia para "disparar cohetes de vara" ${ }^{46}$. La cual fue concedida al poco tiempo.

\subsection{El Corpus, una fiesta en el punto de mira}

Una de las celebraciones esenciales en el calendario cristiano era la del Corpus Christi, en la que el Santísimo Sacramento recorría las calles más importantes de la ciudad, una vez finalizada la celebración litúrgica correspondiente. Como es obvio imaginar, no estuvo ausente de intervenciones estatales y eclesiásticas para adecuar el comportamiento de los que intervenían en ella a los cánones ilustrados y al tipo de religiosidad que se pretendía imponer.

Una de las prohibiciones más polémicas fue la de las danzas de mujeres y diablillos en $1777^{47}$. En Granada, su corregidor fue el encargado de denunciar este tipo de actos por el "mal uso de estas danzas, sobre todo la de diablillos, hay una muchedumbre de muchachos que la

42. ARChG, leg. 1397, n. $^{\circ} 03$.

43. ARChG, leg. S168, n. ${ }^{\circ}$ 09, sin foliar. 1747, 1785, 1804 y 1819.

44. ARChG, leg. 4435, n. ${ }^{\circ} 17$, sin foliar. 1781

45. ARChG, leg. 4435, pieza 17.

46. ARChG, leg. 4434, n. ${ }^{\circ} 05$, sin foliar. 1799.

47. A. Garrido Atienza (1889), 73. En esta obra decimonónica el autor describe cómo era el desfile que acompañaba al Corpus. 
siguen, son campestres, causan en el templo irreverencias al Santísimo Sacramento" 48 .

El Consejo de Castilla le responde prohibiendo estas danzas y diablillos, por "abusos y desórdenes que causan en calles y la iglesia, por modo y forma en que la practican" 49 .

En Granada se reunió a los pocos días un cabildo extraordinario para la redacción de un auto protestando por esta prohibición, puesto que argumentaban que así perdía todo su esplendor la procesión del Corpus Christi, "se invierte la antigua costumbre y se degrada la regalía de esta ciudad" 50 .

De nuevo, en 1780, llegó desde Madrid una cédula real en la que se mandaba no permitir estas danzas y gigantones, porque no cumplían con el decoro exigido en este tipo de festividades religiosas tan señaladas. Argumentan que en la villa de Madrid, desde 1772 ya no se hacían este tipo de prácticas por orden real, por "desautorizar la procesión y el culto del Santísimo Sacramento"51. Asimismo, expresan que en Roma, ya hace años en los que tampoco se llevan a cabo estas prácticas por las muchas incidencias que ocasionaban, "sólo sirven para aumentar el desorden y distraer o resfriar la devoción" 52 .

El problema venía de que el comandante de la ciudad ${ }^{53}$ eludió este requerimiento y no mandó ni a un solo soldado de su tropa para desfilar. Para convencerlo fueron varios caballeros veinticuatro junto a dos jurados comisarios al cuartel, pero no consiguieron "siquiera verlo" 54 . Este comandante se excusó diciendo que estaba atendiendo asuntos más importantes.

De este documento es muy interesante cómo se enumera el desfile que iba escoltando al Corpus unos años antes cuando sí iban soldados de distintos cuerpos militares, "en la puerta de la catedral ha marchado la tropa de caballería delante de todos y la de infantería la ha cerrado, después el presidente de la Chancillería, el capellán, el caballerizo, receptor y pajes, luego el oficial, luego tambores, otro oficial en medio y luego demás soldados y luego otro oficial. Así toda la procesión. Al entrar se pone en fila

48. AHMG, caja 00907, n. ${ }^{\circ} 0036$, sin foliar. 1777.

49. AHMG, caja 00907, pieza 0036.

50. AHMG, caja 00907, n. ${ }^{\circ} 0036$, sin foliar.

51. AHMG, caja 01194, n. ${ }^{\circ} 0021$, sin foliar. 1772.

52. AHMG, caja 01194, n. ${ }^{\circ} 0021$.

53. AHMG, caja 00907, n. ${ }^{\circ} 0037$, sin foliar. 1772.

54. AHMG, caja 00907, pieza 0037. 
la tropa hasta que entra toda la procesión, los últimos son el presidente de la Chancillería y el capellán" 55 .

Un incidente de este tipo ocurrió en 1774 , el cabildo municipal le insta al Consejo Real un permiso de siete escaños "para festividad y funciones y la Junta de Propios y Arbitrios" ${ }^{56}$. La descripción de cómo eran estos asientos se encuentra muy detallada. Incluso se incluye un anexo con un boceto de cómo eran estos asientos.

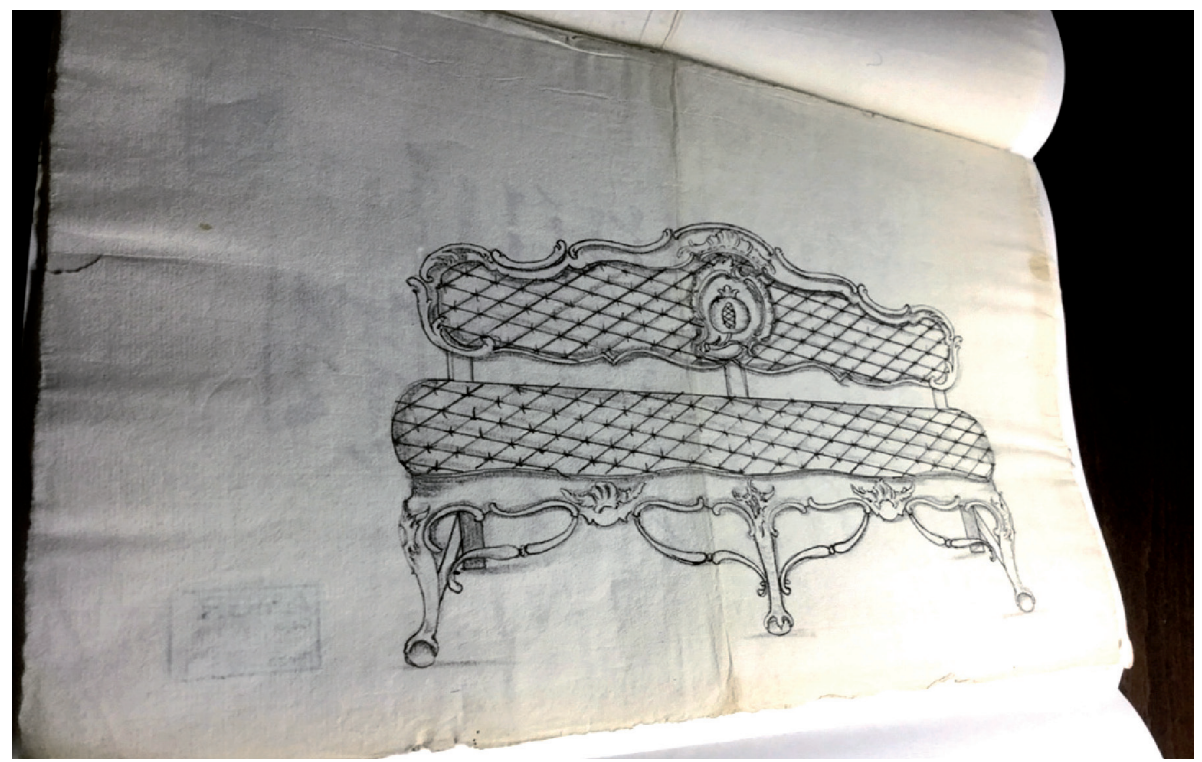

Imagen 1. Archivo Histórico Municipal de Granada, caja 01194, n. ${ }^{\circ}$ 0079, 1774.

\section{CONCLUSIONES}

La Ilustración y la religiosidad del pueblo llano fueron, a lo largo de la centuria del Setecientos, dos elementos encontrados. Las autoridades políticas y eclesiásticas intentaron luchar por su supremacía y su superioridad con medidas represivas, amenazas, lanzando ultimátum, multas y enjuiciamientos para lograr sus objetivos de controlar, en unos casos, o suprimir en otros, ciertas manifestaciones que el pueblo llano había venido haciendo durante siglos.

56. AHMG, caja 01194, n. ${ }^{\circ} 0079$, sin foliar. 1774. 
El tercer estado, ante todos los intentos de reforma y cambios por parte de esta burocracia del siglo XVIII, que siempre se mostró reticente a innovar o a hacer las cosas de otra forma de cómo lo habían aprendido durante generaciones.

Dentro de estas tradiciones tan arraigadas nos encontramos a las asociaciones religiosas formadas por laicos que son las cofradías y hermandades. Estaban enormemente extendidas por toda la geografía castellana y aragonesa dieciochesca.

El pueblo llano intentó proteger con sumo cuidado estas congregaciones religiosas, puesto que eran uno de los pocos mecanismos de promoción social que poseían para hacerse ver ante los más poderosos.

Tras la lectura de esta documentación tan variada, se detecta una enorme preeminencia de los temas de etiqueta, los cuales eran de suma importancia para toda la sociedad del Antiguo Régimen. En los acompañamientos a las procesiones, entre las que podemos destacar la del Corpus, las principales autoridades de la ciudad se querían hacer notar entre la multitud.

Por último, es necesario enfatizar en el valor que tenían los pleitos en una sociedad tan desigual como la del Antiguo Régimen. Eran uno de los pocos mecanismos que tenía la gran masa de los no privilegiados de hacerse notar en una sociedad que hacía por ignorarlos; en esencia, su forma de desafiar al poder.

\section{BIBLIOGRAFÍA}

ABBAD, Farid (1977), "Le confrérie condamnée ou une espontanéité festive confisquée: un autre apect de 1 'Espagne á la fin de l'ancien régime”, Melánges de la Casa Velázquez, 12, pp. 361-384.

Álvarez Santaló, León Carlos (ed.) (1991), Las cofradías de Sevilla en el siglo de las crisis, Universidad, Sevilla.

Arias de Saavedra Alías, Inmaculada y López-Guadalupe Muñoz, Miguel Luis (2002), La represión de la religiosidad popular. Crítica y acción contra las cofradías en el siglo XVIII, Universidad, Granada.

Arias de SaAvedra Alías, Inmaculada y López-Guadalupe Muñoz, Miguel Luis (2008), "La represión de las Cofradías en el Reinado de Carlos III", Tercerol. Cuadernos de Investigación, 12, pp. 75-92.

Arias de Saavedra Alías, Inmaculada y López-Guadalupe Muñoz, Miguel Luis (2017), "Las cofradías españolas en la Edad Moderna desde una óptica social. Tres décadas de avance historiográfico", Cuadernos de Estudios del Siglo XVIII, 27, pp. 11-50.

Domínguez Ortiz, Antonio (1988), Carlos III y la España de la Ilustración, Alianza, Madrid. 
Egido, Teófanes (1987), "La religiosidad de los Ilustrados”, en R. MÉndez Pidal y J. M. Jover Zamora (dirs.), Historia de España, vol. 31, Espasa Calpe, Madrid, pp. 398-431.

Garrido Atienza, Miguel (1889), Las fiestas del Corpus. Antiguallas granadinas, Imprenta de José López Guevara, Granada.

Gómez Martínez, Enrique (2008), "Las cofradías de la Virgen de la Cabeza y su suspensión en el reinado de Carlos III", Boletín del Instituto de Estudios Giennenses, 197, pp. 93-117.

López Arandia, María Amparo (2003), "Desamortización de cofradías en la ciudad de Jaén: fondos documentales", Memoria Ecclesiae, 22, pp. 267-282.

LóPEz MuÑoz, Miguel Luis (1994), "La fiesta religiosa en la diócesis de Granada (1750-1825). Opinión, control y represión”, Chronica Nova, 21, pp. 239-278. LóPeZ-Guadalupe Muñoz, Miguel Luis (2002), "Debate y reacción a las reformas ilustradas: maniobras legales de las cofradías a finales del siglo XVIII”, Chronica Nova, 29, pp. 179-216.

Lozano Ruiz, Carlos (2013), "Asistencia social y cofradías en el Antiguo Régimen. Historiografía, líneas de investigación y perspectivas”, Chronica Nova, 39, pp. 19-46.

Mantecón Movellán, Tomás (1990), Contrarreforma y religiosidad popular en Cantabria, Universidad de Cantabria, Santander.

Martín García, Alfredo (2006), "Ilustración y religiosidad popular. El expediente de cofradías en la provincia de León (1770-1772)", Estudios Humanísticos. Historia, 5, pp. 137-158.

Romero SAMPer, Milagrosa (1991), Las cofradias en el reformismo de Carlos III, Fragua, Madrid.

Plaza Orellana, Rocío (2018), Los orígenes modernos de la Semana Santa de Sevilla. El poder de las cofradías (1777-1808), El Paseo, Sevilla.

Rumeu de Armas, Antonio (1944), Historia de la previsión social en España. Cofradias, gremios, hermandades y montepios, Revista de Derecho Privado, Madrid. 